\title{
The Effect of Local Expenditure, Local Wealth Level, Audit Opinion, and Audit Findings on the Performance of Indonesian Local Governments
}

\author{
Luna Nur Amalina, Mahendro Sumardjo \\ Universitas Pembangunan Nasional Veteran Jakarta, Indonesia \\ lunanuramalina@gmail.com
}

\begin{abstract}
This study aims to determine the effect of local expenditure, local wealth level, audit opinion, and audit findings on the performance of local governments. This study uses the quantitative method, the hypothesis testing with multiple linear regression analysis was used, using SPSS version 23. The population is the local governments of Districts/Cities in Indonesia. The sample is 489 data samples were collected. Results obtained from testing showed that local expenditure, local wealth level, and audit opinion significantly affect the performance of local governments. Meanwhile, audit findings do not have a significant effect towards the Performance of Local Governments. Future studies are expected to be able to add more variables that have not been used in this study, such as government size, local standing, and intergovernmental standing.
\end{abstract}

Keywords: Local expenditure, local wealth level, audit opinion, audit findings, performance.

\section{Introduction}

In the implementation of region autonomy according to relevant laws that apply, the central government delegates authority and responsibility towards local governments in managing and promoting the welfare of the people (Noviyanti \& Kiswanto, 2016). The President Law No. 105 Year 2000 attaches a standard for local finance management, which can be accounted for based on the principles of fairness and obedience. With the goal towards good governance, performance measurement becomes one of the fundamental factors. This must also be supported by the operational characteristic of an entity, as well as assessment towards the various indicators of performance in each local government. This function comprises of the rate of efficiency and effectivity of the operational execution of activities which aim to reach the goals and targets that have been set. The President Law No. 6 Year 2008 states that one of the evaluations towards the execution of local governments is the performance evaluation of the execution of local governments (EKPPD). Furthermore, this regulation is complemented by the Minister of Internal Affairs Law No. 73 Year 2009 regarding the evaluation procedure of performance evaluation of local government execution, as well as Clause 5 of the Minister of Internal Affairs Law No. 73 Year 2009, which states that the EKPPD uses the LPPD as the main source of information. The implementation of EKPPD is done to evaluate the performance of local government execution to increase performance based on the principle of good governance. The EKPPD method is used by assessing the total composite index of the performance of local government execution. The total of the index is the addition of assessment results that cover work performance, and index of material relevance.

The index for work performance is measured by assessing the decision making level aspect, and analysis towards performance interpretation (Peraturan Pemerintah RI Nomor 6 Tahun 2008). The accountability principle is the basis of good governance management, and is the main goal in the reformation of the public sector. The implementation of this principle in the governmental sector is done through the explanation of information and disclosure of financial and non-financial activities that include both the central government and other parties that possess the authority to have knowledge on the said reporting (Bappenas, 2002). The LKPD is a comparison document used to assess financial performance, which will later be audited by the BPK in testing the worthiness of the financial report (Noviyanti \& Kiswanto,2016). Obtaining the Unqualified opinion indicates a commendable effort, however it is not the main responsibility of the local government that produces an accurate financial report. Due to this fact, there are still many frauds that negatively impact the region (Amirsyah, 2019). Based on the IHPD BPK SEMESTER I (2018), there are still reductions in opinions in the last 5 years (2013-2017), which were given by the BPK to the local government, as a result of a weak internal control system and disobedience towards regulations. Aside from the development of opinion in each region, other problems related to the $3 \mathrm{E}$ aspect (Economy, Efficiency, and Effectivity) were still found. This causes material losses towards the country. It is caused by the ineffectiveness in standards or guidelines, ineffectiveness of governance in the entity, lack of data sources in the educational aspect, and other factors 
related to effectivity monitoring (IHPS BPK, 2014). A distinct characteristic in a local government can be categorized in its revenue.

Based on the excellence, of a local government in producing output based from a financial aspect, or people's prosperity. Support from those influential potentials becomes the distinguishing characteristic of a region, especially in regards to the wealth of the region, which originated from local own-source revenue, retrieved from the region's tax, retribution, result of local wealth management, and other lawful local revenue (Alpi \& Ramadhan, 2018; Ermawati \& Aswar, 2020). The significant strengthening of funds is expected to be able to increase the aspect of regional independence optimally, a special form of public service activities, and debureaucracy of governmental governance. However, this expectation has not been fully realized. Due to this, it can aid the increase of the quality of Local Budget expenditure, which includes budgeting, which includes the utilization of technology and information to create performance optimization. Furthermore, the aim of this study is to determine the effect of local expenditure, local wealth level, audit opinion, and audit findings, towards the performance of local governments.

\section{Literature Review}

Theory: This study utilizes the agency theory. The concept of the agency theory in the public sector involves three parties, which includes the first party, the auditor, which is the party that audits the accountability of the second party towards the third party, and provides attestation towards the third party. The principal is represented by the people's representatives, which are the DPR/DPD/DPRD (The National/Regional/Local House of Representatives). The second party (auditee) is the entity or government that executes the management function (agent), which is the entity that is responsible towards the third party, whose accountability is checked by the first party. The third party (acceptor of accountability and audit findings) is the BPK RI (Audit Board of the Republic of Indonesia) as an audit function, which is to request liability from the second party, and receive the audit findings report from the first party (Rai, 2008).

Local Government Performance: The President Rule No. 8 Year 2006 states that performance is the output or result of an activity or program that has or will be achieved in relation to the usage of the budget, whose quantity and quality can be measured. The performance of local government execution is the achievement of the execution of local governmental affairs that is measured through input, process, output, results, benefits, and impacts (Putri \& Aswar, 2020). The President Law NO. 6 Year 2006 has explained the definition of the EKPPD, which is a process of data collection and analysis conducted systematically, towards the performance of local government execution. In the performance measurement system, information is mainly sourced from the LPPD, as well as other complementary information such as the accountability report of the Local Budget execution, local financial information, and performance reports in institutions within the local government. According to Zai (2016), the aim of the EKPPD is to determine the success of local government execution in regards to the utilization of rights achieved by the region with a planes output and outcome achievement, conducting comparisons towards the performance achievement rate of one region to another in the provincial and national area, as well as becoming feedback and recommendation for the region to drive the increase of the performance of local government execution.

Hypothesis Development: The development of hypothesis in this study is based on factors that are suspected to have an effect towards the increase and decrease the performance of local governments in Indonesia.

Local Expenditure: The criteria of local expenditure can be detailed in economic characteristics and function characteristics, which are: subsidies, grants, and social aid, all of which has an individual role in its function as a local government project regarding the construction of residences and public facilities, the wide reach of tourism in each region, religious facilities, education, as well as social protection (Pradana, Sudrajat, \& Amah, 2019). According to Alhajjriana, Nor, and Wijaya (2017), there are types of local expenditures, such as direct and indirect expenditure, as well as expenditures for mandatory government affairs and voluntary affairs with the same objective, which is to upgrade the people's quality of life, provide better services to the people, as well as providing proper facilities to the public. 
One of the successes of local government performance are indicated by the increase of infrastructure construction that is arranged based on the portion in the Local Budget. In the agency theory relationship, the local government is the agent of the legislation and public, in which there is a tendency for one or both parties to maximize their own interest. During the budgeting of local expenditure, a budgetary slack may occur, which is the amount of budgeted local expenditure that does not reflect the real local expenditure, and therefore renders performance that is not optimal. A study by Muid (2014) showed that local expenditure does not have a significant effect towards the performance of local governments in Districts/Cities in the West Java Province.

$\mathbf{H}_{\mathbf{1}}$ : Local Expenditure has a significant effect towards the Performance of Local Governments in Indonesia.

Local Wealth Level: Artha et al. (2015) assumed that the wealth level of a local government can be viewed from the total amount of Local Own-Source Revenue (PAD). This can be stated, since there are several factors that support the revenue of a region, viewed from its resources management. Local government performance that has an additional value towards its Local Own-Source Revenue is deemed to be capable in increasing the independence of its region's own potentials. This strengthens the role of the local government as an agent that receives authority from the central government, which can be trusted in managing their own region's resources. The success of the local government in increasing local wealth through Local Own-Source Revenue, will in the end increase the performance score that is received from the central government (Qowi, Jatmiko, \& Prabowo, 2017). In the perspective of the agency theory, the success of a local government in undertaking its role as an agent can be viewed from the performance of the local government in executing its authorities to manage their own resources, in which one of the indicators can be seen from the amount of Local Own-Source Revenue (PAD). The studies conducted by Artha et al. (2015); Muid (2014); Qowi et al. (2017); as well as Sudarsana and Rahardjo (2013), showed that local wealth level has a significant effect towards the performance of local governments.

$\mathbf{H}_{2}$ : Local Wealth Level has a significant effect towards the Performance of Local Governments in Indonesia.

Audit Opinion: According to Andani and Respati (2019), the obtainment of an unqualified opinion enables a local government to be assessed well and its financial reports can be trusted. The fulfillment of financial reports follows standards, disclosures, obedience towards regulations, and effectiveness of the internal control system. The performance of a local government that obtains an unqualified audit opinion will also indicate a good EKPPD score as well. This assessment is proxied from various assessments within the reporting of the EKPPD. The higher the audit opinion produced, the better the performance of the government. The agency theory states that to achieve optimal results sustaining from the unqualified audit opinion, local governments must always provide complete information to the principal, which is the people, in order to not provide excessive information asymmetry. The studies conducted by Andani and Respati (2019); Dewata et al. (2018); as well as Sutopo dan Siddi (2018), showed that audit opinion bas a significant effect towards local government performance.

$\mathbf{H}_{3}$ : Audit Opinion has a significant effect towards the Performance of Local Governments in Indonesia.

Audit Findings: Audit findings attach case findings of the BPK towards local government financial reports regarding violations that has been conducted in a region towards conditions of internal control or regulations that apply. Follow-ups that are executed well will provide a quality result of the financial report, which can reflect good governance. This effort by the local government would certainly impact regulations regarding services to the people, in order to promote the people's welfare. Therefore, more audit findings show improper financial management in a local government, which would affect the performance measurement of the local government. In the implementation of the agency theory, the local government acts as an agent, and the people act as the principal, in which information asymmetry can possibly occur. This is due to the fact that local governments possess more information regarding the resources owned by the region, compared to the people, and only prioritizes its own interest. Therefore, this increases the number of BPK examinations. Examinations by the BPK should be able to be set as a mechanism to minimize risks in the local government scope. The study conducted by Susanti et al. (2016) shows that audit findings has an effect towards local government performance.

$\mathbf{H}_{4}$ : Audit Findings has an effect towards the Performance of Local Governments in Indonesia. 


\section{Research Methodology}

The population used in this study is all the District/Cities governments in Indonesia of 2017, which consists of 396 Districts and 93 Cities. The district/city governments were selected based on the phenomenon of this study, which shows that performance cases in Indonesia are most prevalent in district/city governments. The sample technique used in this study is the purposive sampling method. The hypothesis testing method used in this study is multiple regression method, aided with the SPSS version 23 program. In this study, data of local expenditure was retrieved from local government financial reports, namely the Budget Realization Report of 2017. Local expenditure was calculated from the total of local expenditure by transforming the total local expenditure of the local government into the form of a natural logarithm form (Alhajjriana et al. 2017). Local wealth level was calculated using Local Own-Source Revenue. According to Amyulianthy et al. (2016), the wealth of a local government is proxied with the ratio of local own-source revenue towards total revenue. Meanwhile, according to Dewata et al. (2018), the measurement of local wealth level can be calculated from the total of local own-source revenue and total revenue. Audit opinion is the assessment of Local Government Financial Reports that are given by the BPK to the local government. According to Aswar (2019), measurement for an unqualified audit opinion is scored 5, Modified Unqualified audit opinion is scored 3, adverse audit opinion is scored 2, and Disclaimer audit opinion is scored 1. Audit findings are cases found by the BPK towards local government financial statements on violations that a region has conducted towards regulations that apply. According to Susanti et al. (2016), disobedience towards regulations can cause losses in the region, potential losses in the nation/region, lack of income, administrative weakness, inefficiency, and ineffectiveness. This variable utilized the amount of audit findings on the Examination Findings Report (LHP) related to weaknesses in the internal control system, and disobedience towards regulations.

\section{Empirical Findings and Discussion}

The effect of local wealth level towards the performance of local governments. This result is also in line with the study conducted by Muid (2014), which used samples from Districts/Cities in the Central Java Province for the period of 2009-2011. In the perspective of the agency theory, the success of a local government as an agent from the central government can be viewed from the local government's performance in executing authorities in managing its own region. In addition to that, the study conducted by Sudarsana and Rahardjo (2013) and Qowi, Jatmiko, \& Prabowo (2017), which used samples from Districts/Cities in Indonesia for the period of 2010-2012. This study conducted a series of analysis, which consists of: descriptive statistics, and hypothesis testing, using the multiple linear regression method. The process of data analysis was done using the Statistical Package for Social Sciences (SPSS) application. The descriptive statistics of the research data is shown in Table 1.

Table 1: Descriptive Statististics

\begin{tabular}{llllll}
\hline Variables & N & Minimum & Maximum & Mean & Std. Deviation \\
\hline Local Expenditure (LE) & 453 & 26.83 & 30.33 & 27.8124 & 0.51959 \\
Local Wealth Level (LWL) & 453 & 0.0047 & 0.8515 & 0.1401 & 0.10623 \\
Audit Opinion (AU) & 453 & 1 & 5 & 4.5 & 0.99 \\
Audit Findings (AF) & 453 & 5 & 30 & 14.26 & 4.517 \\
Performance of Local Government (PLG) & 453 & 1.9434 & 3.4404 & 2.9013 & 0.24642 \\
\hline
\end{tabular}

The Performance of Local Government shows that the minimum score is 1.9434 and standard deviation is 0.2464. Furthermore, Local Expenditure showed a standard deviation of 0.51959, which can be interpreted that the mean is larger than the standard deviation, meaning that the data possesses homogeneity. The Local Wealth Level showed a standard deviation of 0.1062366 which can be interpreted that the mean is larger than the standard deviation, meaning that the data possesses homogeneity. Audit Opinion showed a standard deviation of 0.99 which can be interpreted that the mean is larger than the standard deviation, meaning that the data possesses homogeneity. Audit Findings of District/Cities in Indonesia has a nominal of 14.26 with a 
standard deviation of 4.517, which can be interpreted that the mean is larger than the standard deviation, meaning that the data possesses homogeneity (Sekaran \& Bougie, 2013). The classical assumption test, consisting of the normality test, heteroscedasticity test, and multicollinearity test, shows that all classical assumption tests have been fulfilled and the double linear regression test can be performed. The hypothesis testing used the multiple linear regression test shown in Table 2.

Table 2: Result of Multiple Regression Linear Regression

\begin{tabular}{|c|c|c|c|c|c|c|}
\hline \multicolumn{2}{|c|}{ Model } & \multicolumn{2}{|c|}{ Unstandardized Coefficients } & \multirow{2}{*}{$\begin{array}{l}\text { Standardized } \\
\text { Coefficients } \\
\text { Beta }\end{array}$} & \multirow[t]{2}{*}{$\mathbf{t}$} & \multirow[t]{2}{*}{ Sig. } \\
\hline & & B & Std. Error & & & \\
\hline \multirow[t]{5}{*}{1} & (Constant) & 1.190 & 0.576 & & 2.067 & 0.039 \\
\hline & LE & 0.043 & 0.021 & 0.090 & 2.027 & 0.043 \\
\hline & LWL & 0.856 & 0.104 & 0.369 & 8.234 & 0.000 \\
\hline & $\mathrm{AO}$ & 0.097 & 0.009 & 0.391 & 10.425 & 0.000 \\
\hline & $\mathrm{AF}$ & -0.003 & 0.002 & -0.050 & -1.371 & 0.171 \\
\hline
\end{tabular}

Based table 2, the first hypothesis is the effect of local expenditure towards the performance of local governments. Analysis done using the partial test (t-test) shows that local expenditure coefficient is positive, which means that an increase in Local Expenditure will in turn increase the performance of the local government. Therefore, it can be concluded that $\mathrm{H}_{\mathrm{a}} 1$ is accepted, which means that Local Expenditure has an effect towards the Performance of Local Governments. The result of this study is not in line with Muid (2014), who conducted a study using samples from Districts/Cities in the West Java Province for the period of 20092011. Therefore, Local Expenditure does not have an effect towards the Performance of Local Governments. Local Expenditure has a positive effect towards the performance of local governments, which means that local expenditure in each local government is able to execute its region's duties in increasing the life quality of the people, providing good services to the people. As well as realizing proper facilities for the public. Infrastructure is built based on the portion in the Local Budget, and reflects the real capacity of local expenditure, in producing optimal performance. Local Expenditure, which is defined as the deduction of net wealth in a relevant budget year, must have a real impact and potential to promote the people's welfare, as well as the conditions and potentials of each region's strengths. It is also a development of standards used for performance evaluation, and instrument to motivate employees, and as a coordination tool for all activities from various work units. Therefore, the more Local Expenditure that is budgeted in every local government, also requires full responsibility for each local government.

To manage that local expenditure. This can be implemented according to the agency theory, which explains that the central government and the local government must collaborate when doing budgeting, so that there is no budgetary slack, to reflect that the local expenditure capacity can produce optimal performance. The result is proven in this study with the largest local expenditure budget belonging to the Madiun District, with Rp.14,804,230,828,255.70, with an EKPPD score of 3.2240, which is included in the national first rank of provincial local governments, which is the East Java Province. Analysis done using the partial test (t-Test) shows that local wealth level coefficient is positive, which means that an increase in Local Wealth Level will in turn increase the performance of the local government. Therefore, it can be concluded that $\mathrm{Ha} 2$ is accepted, which means that Local Wealth Level has an effect towards the Performance of Local Governments. This result is in line with the study conducted by Artha, Basuki, \& MT (2015), which used samples from Districts/Cities in the NTB Province for the period of 2011-2013. Therefore, this result is in line with the study result which states that an increase in budgeted local expenditure, will increase the score of the local government's performance. The result of the study showed that the Local Wealth Level variable has a significant and positive effect. Therefore, an increase in local wealth level will increase the score of the local government's performance. Local Wealth Level meant in this study uses the total of Local Own-Source Revenue. 
Local Wealth Level has a positive effect towards local government performance, which means that a local government with a large Local Own-Source Revenue explains its success in acting as the agent that receives authority from the central government in managing its own region's resources. This success indicates that the local government can increase the performance score received from the central government. Local OwnSource Revenue is the representation of the realization of a region's capacity in utilizing potentials as best as possible. The larger the Local Own-Source Revenue generated, the more financially independent the region in funding its government as a service effort to the people, and are expected to manage and utilize the wealth that they have well. The result of the study showed that Local Expenditure does not have a significant effect. This also provides a correlation success factor of region autonomy. An increase in Local Own-Source Revenue can affect the increase of total revenue and infrastructure of local government performance. A large Local Own Source Revenue shows the success of a local government that acts as an agent that receives authority from the central government. To manage their own region's resources this result is proven in this study with the Wealth Level, assumed to use the value of local own-source revenue, belonging the Bandung District with Rp.3,949,679,204,306.49, and an EKPPD score 3.2534 is the highest in the nation and among districts with a status of VH (Very High). Similarly, the Tangerang District with Rp.2,814,684,784,439.83 and an EKPDD score 2.8858 has a status of $\mathrm{H}$ (High) in the rank and status of district government performance nationally.

Therefore, this study states that the increase of Local Wealth Level shows an increase of local government performance, score received from the central government. The third hypothesis is the effect of audit opinion towards the performance of local governments. Analysis done using the partial test (t-Test) shows that audit opinion coefficient is positive, which means that an increase in Audit Opinion will in turn increase the performance of the local government. Therefore, it can be concluded that $\mathrm{Ha} 3$ is accepted, which means that Audit Opinion has an effect towards the Performance of Local Governments. This result is in line with the studies conducted by Andani \& Respati (2019); Aswar (2019); Dewata et al. (2018); as well as Sutopo and Siddi (2018), which used samples from Districts/Cities in the whole of Indonesia in the period of 2010-2018. The result of the study showed that Audit Opinion has a significant and positive effect. This means that more Unqualified audit opinion received shows better performance in the local government. Audit Opinion has a positive effect on the performance of local government, which means that unqualified audit opinions obtained show that the financial results are reliable, and becomes evidence for the financial statements made. Local governments that obtain an unqualified audit opinion, have a higher performance based on EKPPD score, since the local government is able to manage its finances well.

The more Unqualified audit opinions obtained, the more the responsibility towards the financial report, which increases public trust. However, a good audit opinion must be complemented with supporting data. Regulations in districts and cities can increase the caution regarding the management of its region's finances. A better audit opinion indicates a better local government performance. According to the agency theory that applies, local governments must undertake their duty to provide complete information to the principal, who is the people; therefore, it would not cause excessive information asymmetry. This result is proven in this study, using the unqualified audit opinion given to the City of Makassar, which is scored 5 with an EKPPD score of 3.4404. Similarly, the Sidoarjo District was also given a score of 5, with an EKPPD score of 3.4108. Therefore, the result of this study states that more Unqualified audit opinions obtains indicates better local government performance. Lastly, the effect of audit findings towards the performance of local governments. Analysis done using the partial test (t-Test) shows that audit findings does not have a significant effect towards the performance of local governments, with a negative coefficient. Therefore, it can be concluded that $\mathrm{Ha}_{4}$ is rejected, which means that Audit Findings does not have a significant effect towards the Performance of Local Governments. This result is not in line with the study conducted by Susanti et al. (2016), which used samples from Districts/Cities in Sumatera in the period of 2010-2013.

The result of the study showed that Audit Findings has a significant and positive effect. This means that more Audit Findings found, the better the performance in the local government. However, this result is in line with the study conducted by Artha et al. (2015), which used samples from Districts/Cities in the NTB Province for the years 2011-2013. The result of the study showed that Audit Findings does not have a significant effect. This can be interpreted as the local governments in Districts and Cities in the NTB Province have acted quickly in making reparations based on the examination result recommendations. The Audit Findings explained originate from the total number of violation cases in terms of internal control and disobedience 
towards regulations, which are included in the BPK's examination results report. The result in which the BPK's audit findings does not have a significant effect towards the performance of local governments, is presumably due to the fact that the recommendations in the examination result were quickly followed up by each local government, so that it does not affect the execution of duties or government affairs. With the implementation of the agency theory, the local government always provides information and supporting documents to the BPK, as completely as possible, to decrease the possibility of information asymmetry.

\section{Conclusion}

This study aims to determine the effect of Local expenditure, local wealth level, audit opinion, and audit findings, towards the performance of local governments. Upon analysis and hypothesis testing, it can be concluded from this study that Local Expenditure that has been budgeted must have the potential to promote the people's welfare by realizing proper facilities for the public. Local wealth level, which can be determined from local own-source revenue, can elaborate the success of a local government in managing its own local resources as a realization of the capacity representation of a region by utilizing potentials as best as possible. An Unqualifies opinion, given by the BPK, can explain that a local government has executed proper and accountable financial management. Audit Findings does not have a significant effect towards the performance of local governments, presumably since the recommendations attached in the results can be quickly followed up by each local government, and therefore does not influence the execution of duties of governmental affairs. For the local government in Districts/Cities, it is hoped that the result of this study can provide information, to review the performance system of local governments in order to decrease fraud related to performance done by local governments in Indonesia. The further study is able to add more variables that have not been used in this study, such as using government size, local standing, and intergovernmental standing. For the measurement of audit findings, it is advised to use the total audit findings which use the Rupiah value, in order to be able to determine losses in detail.

\section{References}

Alhajjriana, G. I., Nor, W. \& Wijaya, R. (2017). Faktor-Faktor Yang Mempengaruhi Internet Financial Reporting Pemda Dan Implikasinya Terhadap Akuntabilitas Laporan Keuangan Daerah. Persepsi Mahasiswa Akuntansi Dan Mahasiswa Hukum Terhadap Etika Penggelapan Pajak, 15(2), 96-105.

Alpi, M. F. \& Ramadhan, P. R. (2018). Pengaruh karaktrisitik pemerintah daerah dan temuan audit badan pemeriksa keaungan terhadap kinerja keuangan kabupaten/kota. Jurnal Studi Akuntansi \& Keuangan, 2(3), 115-124.

Amirsyah. (2019). Opini WTP, Korupsi, dan Anggaran yang Kredibel. Retrieved February 29, 2020, from www.news.detik.com website: https://news.detik.com/kolom/d-4589121/opini-wtp-korupsi-dananggaran-yang-kredibel

Amyulianthy, R., Khair, J. \& Lysandra, S. (2016). Charactristics and political conncection to local government performance. Jurnal ASET (Akuntansi Riset), 8(2), 1-14.

Andani, M. \& Respati, N. W. (2019). Pengaruh Karakteristik Pemerintah Daerah dan Opini Audit Terhadap Kinerja Pemerintahan Provinsi di Indonesia, 9(1), 111-130.

Artha, R. D., Basuki, P. \& MT, A. (2015). Pengaruh karaktristik pemerintah daerah dan temuan audit BPK terhadap kinerja penyelenggaraan pemerintah daerah. Jurnal InFestasi, 8(2), 195-208.

Aswar, K. (2019). Financial Performance of Local Governments in Indonesia. European Journal of Business and Management Research, 4(6), 1-6.

Bappenas. (2002). Pedoman Penguatan Pengamanan Program Pembangunan Daerah Bappernas \& Depdagri.

Dewata, E., Jauhari, H., Aprianti, S. \& Hijria, E. N. (2018). The Effects of Local Government Characteristics and Audit Opinion on the Performance of District and City Governments in Indonesia. Jurnal Dinamika Akuntansi Dan Bisnis, 5(2), 151-162.

Ermawati, E. \& Aswar, K. (2020). Assessing regional finance independence in Indonesian local governments. European Journal of Business and Management Research, 5(1), 1-5.

Muid, D. (2014). Pengaruh Karakteristik Pemerintah Daerah Dan Temuan Audit Bpk Terhadap Kinerja Pemerintah Daerah Studi Pada Pemerintah Daerah Kabupaten/Kota Di Provinsi Jawa Tengah Periode 2009-2011. Pengaruh Karakteristik Pemerintah Daerah Dan Temuan Audit Bpk Terhadap Kinerja Pemerintah Daerah Studi Pada Pemerintah Daerah Kabupaten/Kota Di Provinsi Jawa Tengah Periode 
2009-2011, 4, 513-527.

Noviyanti, N. A. K. \& Kiswanto. (2016). Accounting Analysis Journal, 3(4), 457-465.

Peraturan Pemerintah RI Nomor 6 Tahun 2008, P. P. R. N. 6 T. (2008). Pedoman Evaluasi Kinerja Penyelangaraan Pemerintahan Daerah.

Pradana, C. W., Sudrajat, A. \& Amah, N. (2019). Faktor-Faktor Yang Mempengaruhi Belanja Daerah Serta Kemungkinan Terjadinya Flypaper Effect Di Keresidenan Madiun, (25), 407-419.

Putri, L. E. \& Aswar, K. (2020). Performance measurement of local government in Indonesia: A conceptual Study. Information Management and Business Review, 12(1), 41-44.

Rai, I. G. A. (2008). Audit Kinerja pada Sektor Publik, Konsep, Praktik, Studi Kasus. Salemba Empat.Indonesia.

Qowi, R., Jatmiko, T. \& Prabowo, W. (2017). Temuan Pemeriksaan BPK Terhadap Kinerja Pemerintah Daerah Kabupaten / Kota Di Indonesia Tahun Anggaran 2012, 6(2007), 1-13.

Sekaran, U. \& Bougie, R. (2013). Research methods for business: A skill building approach (6th Ed.). United Kingdom: John Wiley \& Sons.

Sudarsana, H. S. \& Rahardjo, S. N. (2013). Pengaruh Karakteristik Pemerintah Daerah dan Temuan Audit Bpk Terhadap Kinerja Pemerintah Daerah. Diponegoro Journal of Accounting, 2(6), 1-13.

Susanti, D., Amir, A. \& Tiswiyanti, W. (2016). Pengaruh Karakteristik Pemerintah Daerah, Opini Audit dan Temuan Audit Terhadap Kinerja Pemerintah Daerah.

Sutopo, B. \& Siddi, P. (2018). Capital expenditures and performance of local government administration. Polish Journal of Management Studies, 17(1), 221-231.

Utama, F. R., Evana, E. \& Gamayuni, R. R. (2019). The Effect of Local Government Characteristics on Performance of Local Government Administration, 12(2), 197-208.

Zai, Y. (2016). Evaluasi Kinerja Penyelenggaraan Pemerintah Daerah (EKPPD). Kementrian Dalam Negri Republik Indonesia. 